\title{
Damage evolution during tensile test of austempered ductile iron partially austenized
}

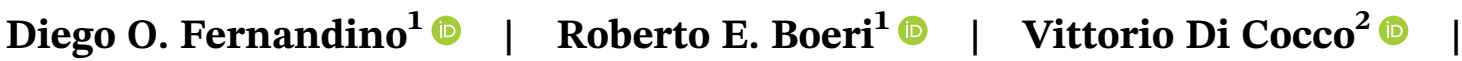 \\ Costanzo Bellini $^{2}$ () | Francesco Iacoviello ${ }^{2}$ (
}

${ }^{1}$ INTEMA, Universidad Nacional de Mar del Plata-CONICET, Mar del Plata, Argentina

${ }^{2}$ DiCeM, Università di Cassino e del Lazio Meridionale, Cassino, Italy

\section{Correspondence}

Diego O. Fernandino, INTEMA, Universidad Nacional de Mar del PlataCONICET, Av. Colón 10850, Mar del

Plata, B7606BVZ, Argentina.

Email: dfernandino@fi.mdp.edu.ar

\section{Funding information}

Universidad Nacional de Mar del Plata, Grant/Award Number: ING 458/16;

Fondo para la Investigación Científica y Tecnológica, Grant/Award Number: PICT 2016-3838; Consejo Nacional de Investigaciones Científicas y Técnicas

\begin{abstract}
The goal of this work is to analyze the damage evolution at microstructural scale of an austempered ductile iron partially austenized during tensile loading. The analysis is carried out by means of step-by-step tensile tests and the specimen's surface observation with optical and scanning electron microscopy. The results show that cracks initiate and propagate firstly at the matrix-nodule interface. Then, as the strain is increased, the initiation and propagation in the metallic matrix take places preferentially inside the ausferritic areas and along the ausferritic-ferritic interface.

Despite the internodular zones tend to localize the plastic deformation, particularly in the ferritic zones, the ausferrite-ferrite interfaces, and the ausferrite itself acts as preferentially sites of cracks propagation. The final fracture is produced by the coalescence of multiple cracks into a single dominant crack leading to the material final fracture.
\end{abstract}

\section{KE Y W O R D S}

ductile iron, fracture surface, in situ testing, material deformation and damage,

micromechanisms of fracture

\section{1 | INTRODUCTION}

Over the last 10 years, a new kind of ductile cast iron (DCI) material, referred to as dual-phase austempered ductile iron $(\mathrm{DPADI})^{1-3}$ has been increasingly studied. The metallic matrix of this material is composed by different quantities of free-ferrite and ausferrite (a fine mix of ferrite and austenite). The aim of this development is to produce materials with similar strength as the pearlitic grades but displaying greater toughness and better machinability.

DPADI is usually obtained by submitting DCI to a partial austenitization by heating within the ternary ferrite-austenite-graphite phase field, followed by an austempering treatment. ${ }^{1,2,4}$ For different intercritical temperatures selected, different amount of austenite will be present in the sample before cooling. The subsequent austempering aims at transforming the austenite into ausferrite, while leaving the ferrite untransformed. The literature reports different mechanical properties based on the amount of ferrite and ausferrite, ${ }^{3,5,6}$ where tensile strength, yield stress, and fracture toughness increases when the amount of ausferrite increases, while elongation diminishes. The fracture surfaces of this material were also evaluated by several authors, ${ }^{6,7}$ but there is not a complete understanding about the sequence and occurrence of damage mechanisms and about the influence of volume fraction of ausferrite on crack propagation and damage evolution. Recent studies allow to improve the understanding about the role of microconstituent, during tensile test by mean of in situ analysis. ${ }^{8-11}$ 
In this work, a step-by-step analysis of DPADI samples during tensile testing is carried out with the goal of analyzing the damage micromechanisms observed under tensile loading.

\section{2 | MATERIAL AND METHODS}

The DCI samples were taken from a $25 \mathrm{~mm}$ "Y" block cast in sand mold. An annealing heat treatment was performed in order to standardize the starting microstructure of the samples to be heat treated to obtain DPADI.

The advance of the austenite precipitation within the intercritical temperature range was characterized in Fernandino et al. ${ }^{12}$ This information was used to design the heat treatment cycle aimed at producing a microstructure consisting of $40 \%$ ferrite and $60 \%$ ausferrite. The heat treatment consisted of a partial austenitization of the samples (previously ferritized), by holding them into the furnace at the selected intercritical temperature for 1 hour, followed by an austempering step in a low-melting-point salt bath at $350^{\circ} \mathrm{C}$ for 90 minutes.

Once the DPADI was achieved, a very small-size specimens (calibrated zones about $2 \mathrm{~mm} \times 16 \mathrm{~mm} \times 1 \mathrm{~mm}$ ) were machined, grinded to $1 \mathrm{~mm}$ in thickness and polished using standard procedures. The small-size tensile sample were tested by using a tensile test machine specially designed to perform a step-by-step analysis. The step-by-step tensile procedure involved loading the tensile test sample intermittently (uniaxial loading conditions at low strain rate) and observing the damage mechanisms at microstructural level using optical an electronic microscopy. The microscopic observations were conducted "in situ" by using a digital microscope Leica VZ105C equipped with a digital microscope camera Leica DVM2000 and a SEM Philips 505.

\section{3 | RESULTS}

\section{1 | Material characterization}

Table 1 lists the result of chemical analysis of DCI used. A fully ferritic microstructure resulting from the annealing heat treatment is shown in Figure 1A. The microstructure after heating the samples at $798^{\circ} \mathrm{C}$ followed by the austempered heat treatment at $360^{\circ} \mathrm{C}$ for 90 minutes is shown in Figure 1B. Ferrite (white), ausferrite (gray), and graphite nodules (dark gray) are observed. After the intercritical heat treatment, the metallic matrix is composed by $40 \%$ ferrite and $60 \%$ ausferrite.

\section{2 | Damage evolution}

Figure 2 shows the metallographic observation of the microscale damage after the final fracture stage. At the beginning of the macroscopic elastoplastic behavior, the microstructural damage involves crack initiation at the matrix-nodule

TA BLE 1 Chemical composition of ductile cast iron (DCI) used (Fe balance, weight \%)

\begin{tabular}{lllllll}
$\mathbf{C}$ & $\mathbf{S i}$ & $\mathbf{M n}$ & $\mathbf{S}$ & $\mathbf{P}$ & $\mathbf{M g}$ & $\mathbf{C u}$ \\
3.32 & 2.36 & 0.31 & 0.012 & 0.016 & 0.033 & 0.62 \\
\hline
\end{tabular}

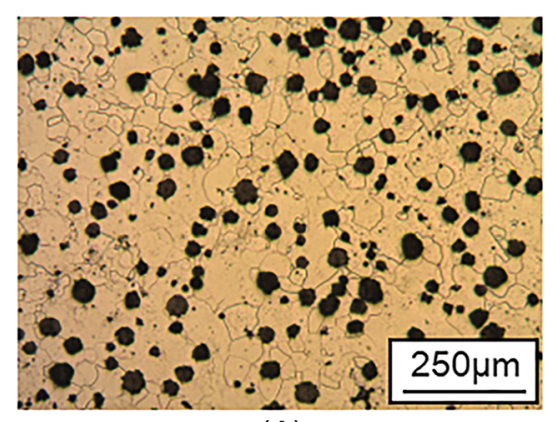

(A)

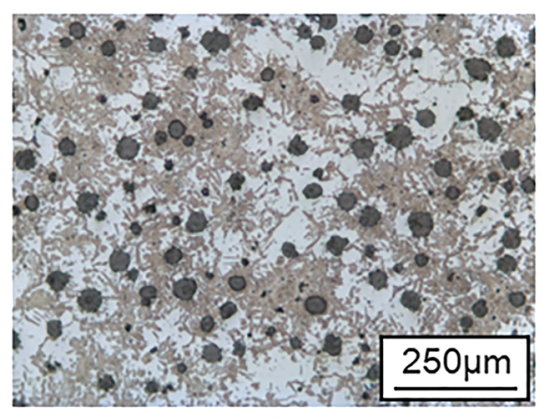

(B)
FIG URE 1 Optical micrography resultant from different heat treatments. A, After annealing and B, after heating the samples at $798^{\circ} \mathrm{C}$ followed by the austempered heat treatment at $360^{\circ} \mathrm{C}$ for $90 \mathrm{~min}$ 
F I G URE 2 Metallographic observation of the microscale damage after the final fracture stage. A, Optical micrography, B, scanning electron microscopy (SEM) image of the final fracture path, $\mathrm{C}$, detail of the plastic deformation around the spheroidal graphite, and $\mathrm{D}$, crack tending to follow the ausferrite acicular morphology during the propagation

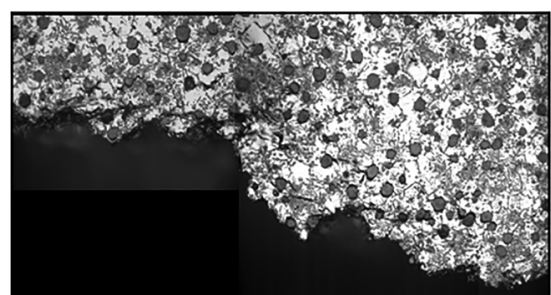

(A)

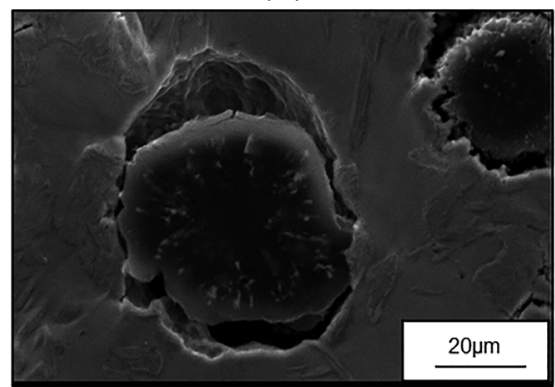

(C)

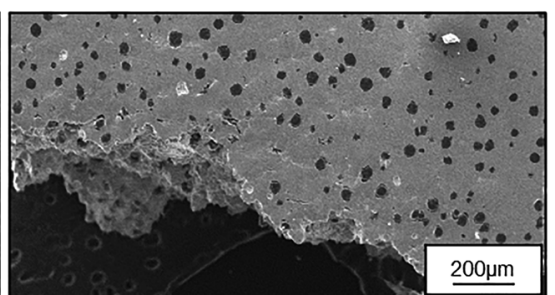

(B)

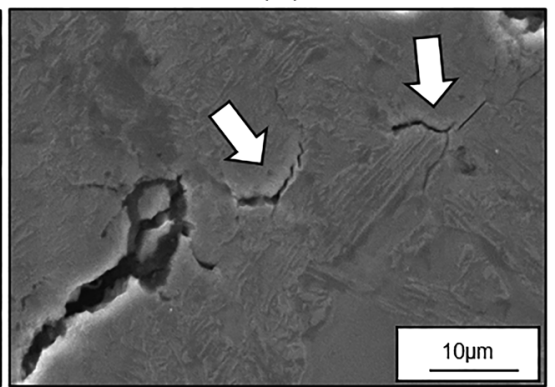

(D)

interface (MNI) and some marks of plastic deformation near the graphite nodules. As the macroscopic strain increases, complete matrix-nodule interface debonding (MND) takes place. Some signs of plastic deformation bands and crack initiation in the metallic matrix are observed along the sample surface. For more advance stage of damage, the beginning of crack propagation is observed. It is worthy to note that cracks preferentially initiate and began to propagate inside the ausferrite areas and through the ausferritic-ferritic interface. An example of crack tending to follow the ausferrite acicular morphology during the propagation is pointed out by a white arrow in the magnification on Figure 2D. Figure 3 shows the crack initiation and propagation in the ausferritic areas of the metallic matrix (pointed out by white arrows) and MNIs.

The final fracture is produced by the coalescence of multiple cracks into a single dominant crack leading to the material final fracture. Despite the internodular zones tend to localize the plastic deformation, particularly in the ferritic zones, the ausferrite-ferrite interfaces and the ausferrite itself are the preferentially sites of cracks propagation. Differently to the observation carried out in a DPADI samples with a metallic matrix consisting of $60 \%$ ferrite- $40 \%$ ausferrite, ${ }^{12}$ when the ausferrite is the predominant phase, the lateral surface near final crack shows a slightly decrement of plastic damage mechanisms. In fact, during the step-by-step loading, the role of ferritic grain boundary in both crack initiation and propagation is also decreased. These observations are consistent with differences in the mechanical proprieties of each phase. However, in order to generalize this observation, additional works considering different fraction volume of ferrite-ausferrite should be undertaken, which are out of the scope of this work.

The resulting fracture surface (Figure 4A) shown two characteristic features: a predominant quasi-cleavage fracture mechanism and areas showing a ductile damage mechanism (pointed out by white and black arrows, respectively, in Figure 4B). Both features are typically found in the fracture surfaces of austempered ductile iron (ADI) ${ }^{13,14}$ and ferritic

F I G U RE 3 Optical micrograph showing the crack initiation and propagation in the ausferritic areas of the metallic matrix (pointed out by white arrows) and matrix-nodule interfaces

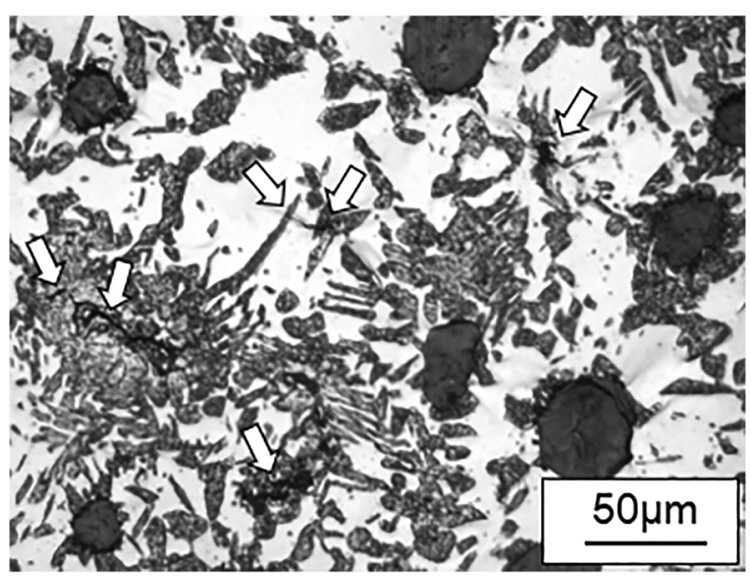




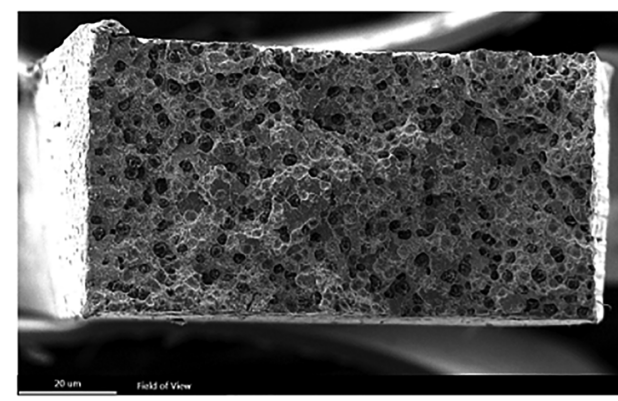

(A)

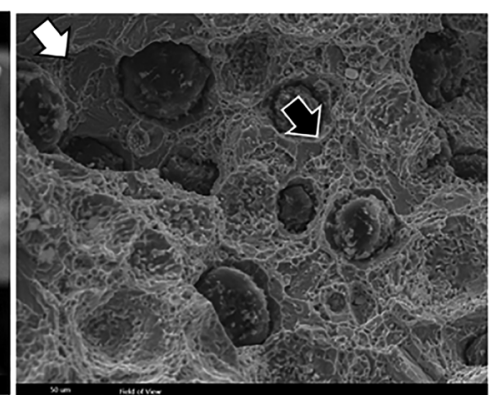

(B)
FIG URE 4 Fracture surface of the small tensile sample resulting from the quasi-static loading condition. Different magnifications

spheroidal graphite cast iron (SGI) ${ }^{11,14,15}$ samples resulting of quasi-static loading conditions. Furthermore, the fracture surface morphology is consistent with a crack propagating predominantly along the ausferrite zones linked with internodular ligaments strained during plastic damage evolution.

\section{4 | CONCLUSIONS}

A step-by-step analysis of ADI partially austenized during tensile testing has been presented. The main findings respect to the damage mechanisms are as follows:

- At the beginning of the elastoplastic behavior stage, the microstructural damage involves crack initiation at the MNI and some marks of plastic deformation near the graphite nodules.

- During the damage evolution, the cracks in the metallic matrix preferentially initiate and propagate inside the ausferrite areas and along the ausferritic-ferritic interface. A complete debonding of the MNI is also observed.

- The final fracture is produced by cracks propagating along the ausferrite and through the internodular ligaments. Consequently, the material failure is achieved from different cracks joining into a single dominant crack.

- The fracture surface resulting from tensile loading shows a predominant quasi-cleavage fracture mechanism in combination with areas showing a ductile damage.

\section{ACKNOWLEDGMENTS}

This research has been supported by grants awarded by Consejo Nacional de Investigaciones Científicas y Técnicas (Bilateral Cooperation Program-2017), Fondo para la Investigación Científica y Tecnológica (PICT 2016-3838), and the Universidad Nacional de Mar del Plata (ING 458/16).

\section{ORCID}

Diego O. Fernandino (1) https://orcid.org/0000-0003-4647-2663

Roberto E. Boeri (1) https://orcid.org/0000-0001-7083-579X

Vittorio Di Cocco (D) https://orcid.org/0000-0002-1668-3729

Costanzo Bellini (iD https://orcid.org/0000-0003-4804-6588

Francesco Iacoviello (1) https://orcid.org/0000-0002-9382-6092

\section{REFERENCES}

1. Aristizabal, R., Hayrynen, K., Foley, R., Griffin, J., Monroe, C. Austemperability of intercritically austempered ductile iron (IADI). AFS Transactions, American Foundry Society, Schaumburg, IL, USA. 2014; 279-286

2. Fernandino DO, Massone JM, Boeri RE. Characterization of the austemperability of partially austenized ductile iron. $J$ Mater Process Technol. 2013;213:1801-1809. https://doi.org/10.1016/j.jmatprotec.2013.05.002

3. Panneerselvam S, Putatunda K, Gundlach R, Boileau J. Influence of intercritical austempering on the microstructure and mechanical properties of austempered ductile cast iron (ADI). Mater Sci Eng A. 2017;694:72-80. https://doi.org/10.1016/j.msea.2017.03.096

4. Basso, A., Martínez, R.A., Sikora, J.A. Development of dual phase ADI. In: Proceedings of the Eighth International Symposium on Science and Processing of Cast Iron, Beijing, China, 2006; 408-413.

5. Chen JK, Chen BT, Tsai JS. Microstructural evolutions and properties of partially austenitizing and austempered ductile irons. Steel Res Int. 2016;87:191-198. https://doi.org/10.1002/srin.201400603 
6. Basso A, Sikora J, Martínez R. Analysis of mechanical properties and its associated fracture surfaces in dual-phase austempered ductile iron. Fatigue Fract Eng Mater Struct. 2013; 7;36:650-659. https://doi.org/10.1111/ffe.12032

7. Kilicli V, Erdogan M. The nature of the tensile fracture in austempered ductile iron with dual matrix microstructure. $J$ Mater Eng Perform. 2010;19:142-149. https://doi.org/10.1007/s11665-009-9386-X

8. Di Cocco V, Iacoviello F, Cavallini M. Damaging micromechanisms characterization of a ferritic ductile cast iron. Eng Fract Mech. 2010; 77:2016-2023. https://doi.org/10.1016/j.engfracmech.2010.03.037

9. Di Cocco V, Iacoviello F, Rossi A, Iacoviello D. Macro and microscopical approach to the damaging micromechanisms analysis in a ferritic ductile cast iron. Theoretic Appl Fract Mech. 2014;69:26-23. https://doi.org/10.1016/j.tafmec.2013.11.003

10. D'Agostino L, Di Cocco V, Fernandino DO, Iacoviello F. Damaging micromechanisms in an as cast ferritic and a ferritized ductile cast iron. Proc Struct Integ. 2017;3:201-207. https://doi.org/10.1016/j.prostr.2017.04.045

11. Fernandino DO, Boeri RE. In-situ microscopic analysis of ferritic ductile iron during tensile loading relation between matrix heterogeneities. Fatigue Fract Eng Mater Struct. 2019;42:2220-2231. https://doi.org/10.1111/ffe.13030

12. Fernandino DO, Di Cocco V, Iacoviello F, Boeri RE. Microstructural damage evaluation of ferritic-ausferritic spheroidal graphite cast iron. Frattura ed Integrità Strutturale. 2020;51:477-485. https://doi.org/10.3221/IGF-ESIS.51.36

13. Fernandino DO, Boeri RE. Fractographic analysis of austempered ductile iron. Fatigue Fatigue Fract Eng Mater Struct. 2015;39(5):583598. https://doi.org/10.1111/ffe.12380

14. Martínez RA. Fracture surfaces and the associated failure mechanisms in ductile iron with different matrices and load bearing. Eng Fract Mech. 2010;77(14):2749-2762. https://doi.org/10.1016/j.engfracmech.2010.07.013

15. Fernandino DO, Boeri RE. Study of the fracture of ferritic ductile cast iron under different loading conditions. Fatigue Fract Eng Mater Struct. 2015;38:610-620. https://doi.org/10.1111/ffe.12266

How to cite this article: Fernandino DO, Boeri RE, Di Cocco V, Bellini C, Iacoviello F. Damage evolution during tensile test of austempered ductile iron partially austenized. Mat Design Process Comm. 2020;e157. https:// doi.org/10.1002/mdp2.157 